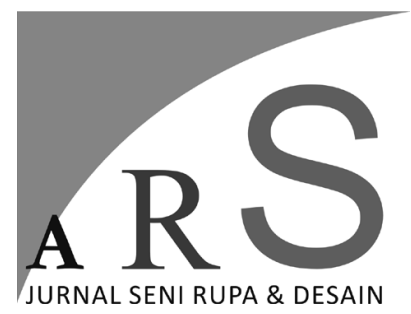

Volume 23 Nomor 1 Januari - Maret 2020

\section{ANALISA POLITIK IDENTITAS DALAM KARYA-KARYA POTRET DIRI AGUS SUWAGE DENGAN PENDEKATAN SEMIOTIKA}

\author{
Satrio Hari Wicaksono, N. Akbar Zuhri
}

\author{
Jurusan Seni Murni, Fakultas Seni Rupa \\ Institut Seni Indonesia Yogyakarta \\ Jln. Parangtritis Km 6,5 Bantul, Yogyakarta 55001 \\ E-mail: shwicaksono@gmail.com
}

\begin{abstract}
ABSTRAK
Penelitian ini bertujuan untuk menggali makna potret diri dari seorang seniman. Potret diri dalam seni rupa seringkali identik sebagai pengungkapan identitas sang perupa. Banyak seniman yang kemudian menggunakan dirinya sebagai frame atau sudut pandang yang menempatkan sosoknya sebagai bagian dari permasalahan yang diangkat dalam karya. Dalam sejarah panjang seni rupa Indonesia, sudah banyak seniman yang berupaya mengangkat tentang trema potret diri sebagai penanda kedudukannya dalam masyarakat, seperti halnya Agus Suwage yang merupakan seniman kontemporer yang kerap menggunakan dirinya untuk mengkritisi nilainilai sosial dalam masyarakat. Penelitian ini akan mencoba memetakan dan membaca perkembangan karya seni potret diri yang dilakukan oleh Agus Suwage. Metode analisa dilakukan dengan menggunakan pendekatan semiotika untuk membaca tanda-tanda yang hadir dalam karya sang seniman. Dengan membaca beberapa karya yang dijadikan perwakilan untuk membaca semangat zaman dn kekaryaan yang dilakukan oleh Agus Suwage.
\end{abstract}

Kata Kunci : Agus Suwage, identitas, potret diri, semiotika

\title{
ABSTRACT
}

This study aims to explore the meaning of self-portrait of an artist Self-portrait in fine arts is recognized as an expression of the artist's identity. Many artists who start using themselves as a frame or point of view that puts their figures as part of the debate raised in the work. In the long history of Indonesian art, many artists have raised the theme of self-portraits as markers of their position in society, such as Agus Suwage who is a contemporary artist who uses crafts to criticize social values in society.

This research will try to map and read the development of self-portrait artworks carried out by Agus Suwage. The method of analysis is done by using a semiotic approach to read the signs that are present in the work of the artist. By reading some of the works that were used as representatives to read the spirit of the times and works carried out by Agus Suwage.

Keywords: Agus Suwage, identity, self-portrait, semiotics 


\section{Pendahuluan}

Permasalahan identitas menjadi sebuah wacana yang penting dalam setiap penciptaan sebuah karya seni, tak terkecuali dalam karya seni rupa. Penggambaran, pengolahan dan penggayaan yang spesifik, unik, dan khusus menjadi sebuah representasi serta penanda dari setiap seniman yang khas dan menjadi pembeda dengan seniman yang lainnya. Semangat kebaruan (novelty) yang menjadi ciri khas dari seni rupa modern menjadi salah satu pemicu yang menggerakkan para seniman untuk menyuarakan ide dan konsep berkesenian mereka secara personal yang berbeda dengan seniman lainnya, Seniman modern berpendirian bahwa pusat, dari mana karyanya lahir terwujud, adalah dirinya sendiri (Yuliman dalam Hasan, 2001 : 71).

Identitas yang hadir dalam sebuah karya merupakan representasi dari jiwa seniman yang berupa akumulasi pengalaman, pandangan, lingkungan dan latar belakang sang seniman. Bagaimana sang seniman mengolah bentuk dan rupa yang sangat identik adalah hasil kreativitas dan proses pengeraman yang panjang dari seniman tersebut. Maka dari itu perwujudan identitas yang muncul di dalam karya seyogyanya adalah gambaran yang jujur dari sang seniman, seperti yang diungkapkan oleh Sudjojono, yang menyerukan agar pelukis harus bertolak dari jiwanya sendiri : lukisan adalah jiwa nampak (Yuliman dalam Hasan, 2001 : 71). Dalam perkembangan sejarah seni rupa di Indonesia, revolusi seni yang menggeser pusat daya cipta masyarakat kepada pribadi perseorangan terjadi pada masa tahun-tahun 1930-an. Pada masa itu timbul gerakan-gerakan kesenian untuk menciptakan seni baru yang merupakan ungkapan pribadi perseorangan, seperti gerakan Pujangga Baru (1933), PERSAGI (1938), dan Pitamaha (1934) di Bali.

Gaya ungkap sebagai penanda identitas sang seniman bisa berwujud dalam berbagai macam bentuk, dari penggunaan karakter yang khas, sapuan yang unik, kombinasi warna yang spesifik, penggunaan potret diri senimannya dan banyak hal lagi. Di antara penanda yang khas tersebut, potret diri sang seniman tentu menjadi hal yang sangat spesifik menandakan "kehadiran" sang seniman secara konkret dan identik pada karyanya. Kebanyakan perwujudan potret diri dalam karya menggunakan pendekatan yang cenderung realis, sebagai upaya untuk mempertegas identitas seniman, namun visualisasi dari masing-masing seniman yang spesifik merupakan upaya untuk "mendefinisikan diri" dengan dunia sekitarnya melalui karya seni. Tujuan penggunaan potret diri dalam karya, menurut Mikke Susanto dibagi menjadi tiga bagian, yaitu menggambarkan tentang identitas \& notasi, eksperimen gaya \& media serta keberpihakan sejarah dan konteks sosial politik (Susanto, 2011 : 317) atau penggabungan antar bagian tersebut. Lewat potret diri, seniman membangun citra, kesan dan sisi sudut pandang yang menentukan "keberpihakan" mereka dalam lingkungan sosialnya.

Sejarah potret diri sebagai gambaran akan kehadiran sang seniman dalam karya pun sudah berlangsung sejak lama. Dalam catatan tertua, yang pertama kali menggunakan wajahnya dalam karya ialah pelukis Jan van Eyck pada tahun 1433, tidak menutup kemungkinan ditemukannya data tentang penggunaan potret diri dalam karya pada periode yang lebih lampau. Semenjak itu banyak seniman kemudian menggunakan sosoknya sendiri sebagai representasi dari kekaryaannya. Walau tak selalu menggunakan wajahnya sebagai gaya ungkap, beberapa seniman besar seperti Leonardo da Vinci, Albrecht Durer, Rembrandt, Gustave Courbet, Vincent van Gogh, Pablo Picasso, Andy Warhol dan beberapa seniman lainnya pernah menggambarkan kehadiran mereka lewat potret diri dalam sebuah karya. Di Indonesia sendiri, perkembangan penggunaan potret diri dalam karya dimulai oleh Raden Saleh, yang sekaligus masih disepakati sebagai seniman modern pertama di Indonesia. Kemudian dilanjutkan oleh seniman pada generasi sesudahnya seperti Sudjojono, Basuki Abdullah, Suparto, Otto Djaja, Ivan Sagita dan masih banyak nama seniman lainnya yang menggunakan idiom potret diri dalam karyanya.

Banyak seniman Indonesia yang menggunakan potret diri sebagai bahasa ungkapnya, namun sedikit yang secara intens menggunakannya secara berkelanjutan dan berulang di beberapa karya, dari sedikit nama seniman tersebut salah satunya adalah Agus Suwage. Banyak sekali dari karya-karyanya selama tiga dekade ini selalu menempatkan permasalahan sosial melalui kacamata dan cermin sosok dirinya. Potret diri seakan menjadi ciri khas 
dari Agus Suwage, walaupun ada juga karyakaryanya di luar potret diri, namun mayoritas yang tampak dari keseluruhan karya yang dipamerkan dan dikenali oleh khalayak umum adalah potret diri, apapun media yang digunakan, baik lukisan, drawing, fotografi dan mix media, tak pernah luput dari pengangkatan tentang kehadiran diri sang seniman dalam karyanya. Menariknya, dalam rentang waktu yang panjang tersebut Suwage selalu menemukan posisi atas refleksi potret dirinya dalam permasalahan sosial masyarakat yang kompleks seolah melebur.

\section{Pembahasan}

Identitas berasal dari bahasa latin "idem" yang berarti sama, yakni mengacu pada karakter khusus individu, anggota kelompok atau kategori sosial tertentu, dapat pula bermakna suatu karakter yang membedakan individu dengan individu atau dengan kelompok lainnya (Prajitno, 2018 : 33). Sedangkan dalam Kamus Besar Bahasa Indonesia disebutkan bahwa Identitas adalah ciri-ciri atau keadaan khusus seseorang; jati diri (www. kbbi. kemdikbud.go.id/identitas).

Dalam perkembangan seni rupa modern, identitas menjadi hal yang esensial dalam proses berkreasi, tak hanya mengedepankan kebaruan (novelty), seni modern juga mengedepankan otentisitas. Tak mengherankan seniman modern berupaya untuk melepaskan dari aturan-aturan baku yang menyetarakan standar 'keindahan', dan berupaya mencari nilai-nilai kebaruan yang berbeda dengan standar tersebut.

Identitas dalam seni rupa merupakan hal yang penting untuk memberikan karakteristik yang khas, personal, dan menjadi nilai pembeda antara seorang seniman dengan seniman lainnya. Pentingnya identitas dalam sebuah karya seni diutarakan oleh Sudjojono seperti berikut :

“...Kecakapan disini tidak berarti teknis saja, tetapi juga diarti tampak 'aku' mereka di tiap-tiap corak kuas yang ada. Bagaimana 'aku' mereka akan tampak, bukan, sebab 'aku' mereka ditiap-tiap kali terdesak oleh 'aku' orang-orang lain, sebab mengkopi. Dan tampak pada 'aku' inilah seyogyanya terletak kebagusan tiaptiap lukisan atau gambar. Kalau 'aku' tadi tidak terlihat, maka dengan sendirinya lukisan-lukisan atau gambar-gambar tadi tidak akan menambah banyaknya bunga lukisan yang ada di dunia ini" (Sudjojono, $2000: 58)$.

Hal inilah yang disebut sebagai Jiwa Kethok' oleh Sudjojono, sebuah penggambaran identitas yang jujur, apa adanya, dan merdeka dari segala ikatan yang berlaku khususnya standar keindahan yang menjadi acuan, selayaknya seniman-seniman modern.

Permasalahan identitas pun tak lepas dari perkembangan zaman, pembabakan zaman dari masa pra-modern, modern dan kini yang kita nyatakan sebagai pasca-modern memiliki latar budaya yang berbeda, konteks sosial yang berlaku pada suatu masa tak dapat disamakan dengan periode yang lainnya, maka standar nilai untuk merekonstruksi dan membaca identitas pun sangat berbeda. seperti yang dikatakan oleh Yasraf Amir Piliang mengenai perubahan identitas dalam lingkup sosial budaya :

"...perbincangan mengenai identitas adalah perbincangan mengenai 'dinamika identitas' itu sendiri, yang selalu bergerak, berpindah, dan berubah sebagai akibat dari sebuah dunia yang dibentuk oleh kesalingbergantungan yang tinggi, saling pengaruh yang kuat, dan persaingan yang tajam di antara unsur-unsurnya; sebuah 'dunia yang berlari' dengan kecepatan yang semakin tinggi, yang telah menggiring masyarakatnya untuk 'berlari' mengikuti irama kecepatan dan percepatan tersebut." (Yasraf dalam Wicaksono, $2002: 7$ )

Penekanan kebaruan yang didengungkan dengan lantang oleh para seniman modern, masih relevan untuk digunakan dalam mengkonstruksi wacana berkesenian saat ini namun dengan sedikit pergeseran nilai, jika pada masa modern proses pergulatan dan pencarian berkutat di dalam seni tersebut, maka kini pembahasannya lebih luas, dengan melibatkan beberapa aspek bidang keilmuan sehingga perkembangan wacana seni menjadi lebih kompleks dan memungkinkan para seniman untuk mengeksplorasi tanpa batas, sehingga pengembangan karakter dan identitas bisa menjadi sangat spesifik dan personal.

Politik identitas merupakan salah satu strategi yang diwacanakan oleh seniman sebagai salah satu cara untuk membentuk identitasnya dalam berkarya. Belum ada catatan resmi kapan politik identitas pertama kali dicetuskan, namun para ilmuwan sosial baru tertarik dan membahas lebih dalam sekitar tahun 1970-an, bermula di 
Amerika Serikat, ketika menghadapi masalah minoritas, jender, feminism, ras, etnisitas, dan kelompok-kelompok sosial lainnya yang merasa terpinggirkan (Maarif, 2012 : 3). Isu-isu kaum minoritas tersebutlah yang juga menjadi identitas dan media untuk menyuarakan 'ketertindasan' dalam karya-karya seni.

Perkembangan wacana yang mengetengahkan sudut pandang kelompok marjinal kemudian banyak merebak seiring berkembangnya periode pasca-modern. Sudut pandang yang berbeda dengan kaum mainsteam atau kaum mayoritas menjadi nilai politis baruyang unik untuk diangkat dalam wacana keseni rupaan, banyak seniman yang kemudian menjadikan politik identitas ini sebagai ungkapnya. Masih segar dalam ingatan ketika boom seni lukis China menguasai peta seni rupa global dunia pada medio 1990-an hingga pertengahan tahun 2000-an. Nama-nama seperti Ai Weiwei, Fang Lijun, Yue Minjun, Zhang Xiaogang dan lainnya menjadi dikenal luas dalam perkembangan seni rupa global. Tentu bukan tanpa alasan khusus para seniman China ini mampu menghentak dan masuk ke dalam panggung yang sebelumnya penuh dengan hegemoni seniman-seniman Barat yang telah berlangsung lama, wacana identitas lokal yang kuat, yang berbeda dengan budaya barat, menjadi nilai tawar baru yang membuka pandangan tentang kebudayaan dan identitas yang selama ini, menurut para pemikir Barat, hanya bersifat tunggal dan searah. Perubahan sosial ini yang kemudian menjadi salah satu pemantik berkembangnya identitas lokal seni rupa di dunia ketiga yang sebelumnya hanya dipandang sebelah mata.

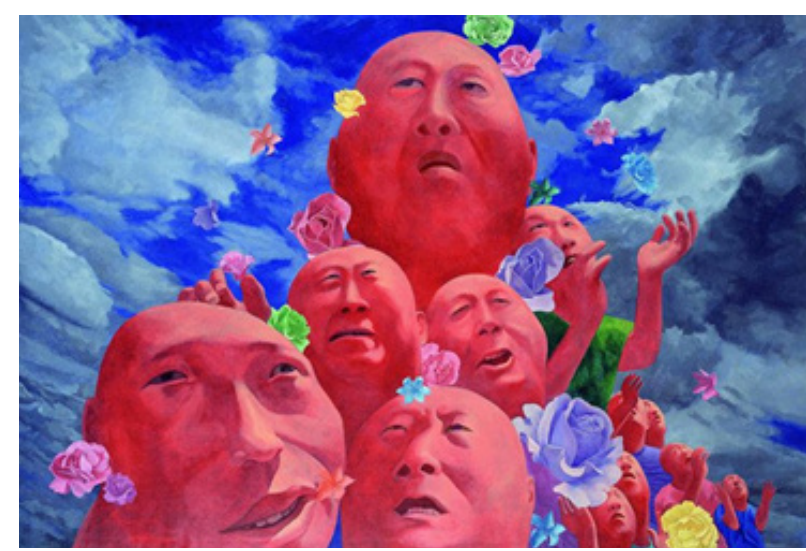

Gambar 1. Karya seniman China kontemporer, Fang Lijun yang menggemparkan dunia seni rupa global (Sumber : http://salchetron.com/Fang-Lijun diakses pada 6 Oktober 2019, pukul 14.22 WIB)

\section{Seni Lukis Potret Diri}

"ifyou cannot capture the essence of your own self, how are you to capture essence of someone else?" - Bridgetbrow

Seperti yang telah disinggung sebelumnya, penggunaan potret diri dalam lukisan yang tercatat pertama kali adalah Jan van Eyck pada tahun 1433 lewat lukisan 'Portrait of a Man in a Turban', dimana ia melukiskan sosoknya dan sang istri dilukiskan secara terpisah, ini juga menjadi pemicu munculnya penggambaran potret diri di Belanda. Belum ada catatan resmi dimana seniman pada periode Renaissance dan masa sebelumnya menggunakan potret dirinya sebagai bagian dari lukisan, walau sebagian ahli menduga bahwa gambar potret seorang pria tua yang digambarkan dengan kapur merah di Turin adalah gambar potret Leonardo da Vinci, dimana sang pelukis menggambarkan sosok dirinya ketika berusia 60 tahun. Hal yang lumrah terjadi mengingat seniman-seniman Renaissance biasanya menggunakan model dalam proses kekaryaannya, dan tak jarang sang pelukis menggunakan sosok dirinya sebagai model.

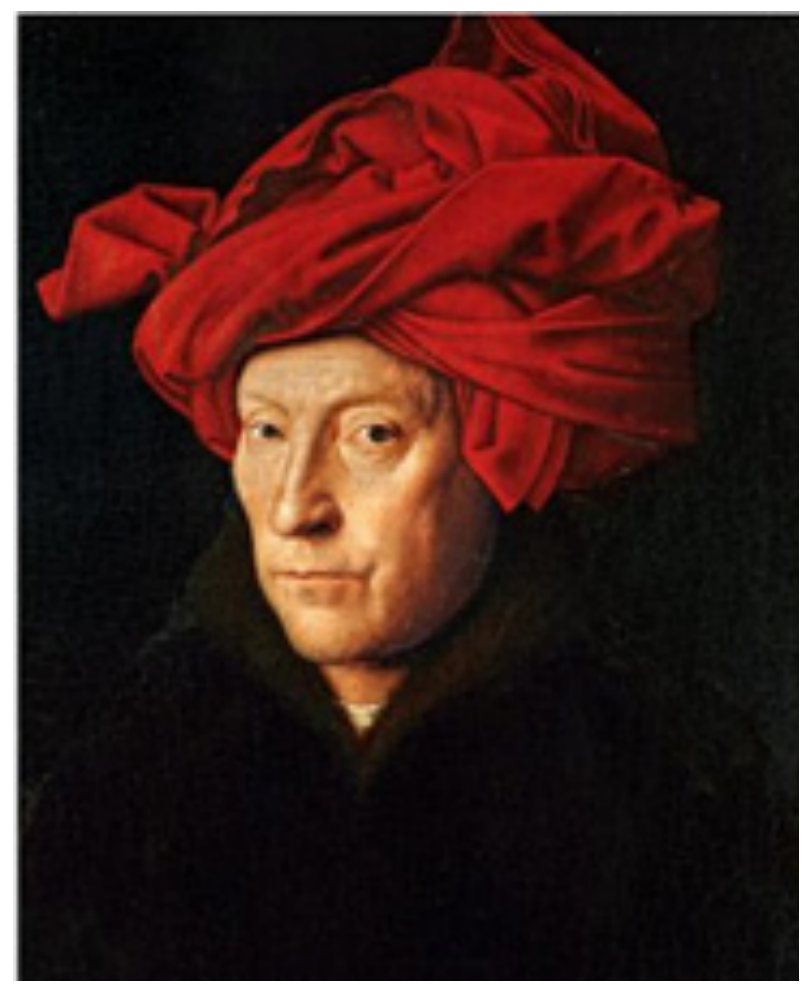

Gambar 2. Karya potret diri Jan van Eyck yang diduga sebagai lukisan potret diri yang pertama

(Sumber : https://www.art.com/products/p12972944sa-i2208828/jan-van-eyck-a-man-in-a-red-turban-selfportrait-of-jan-van-eyck-1433.htm diakses pada 7 Oktober 2019, pukul 13.00 WIB) 
Rizki A. Zaelani mengungkapkan pendapatnya tentang posisi seniman dalam karya seni lukis potret :

"Pada lukisan potret diri, individualitas dirayakan sepenuhnya, tidak hanya dimaksudkan untuk "menunjukkan diri", tapi "diri yang merealisasikan". Lukisan potret diri (sebagai seniman) memang menjadi tempat individualitas didesakkan keluar, bukan hanya tentang gambaran 'luar' tapi juga seluruh gejolak 'di dalam'. Meskipun demikian, realisasi individualitas ini tidak per se jadi pantulan watak personal, tapi juga jadi perkara watak masyarakat yang mengitari sang subjek." (Zaelani dalam Supangkat, 1999 :24-25)

Di Indonesia sendiri, penggunaan potret diri dalam lukisan pertama kali diduga digunakan oleh seniman modern pertama Indonesia, Raden Saleh. Sejarawan Peter Carey menilai bahwa lukisan Raden Saleh bertajuk 'Penangkapan Pangeran Diponegoro' (Belanda : Gevangenname van Prins Diponegoro) yang dilukis pada 1857 menggambarkan sosok sang pelukis dalam karyanya, bahkan tidak hanya satu namun dua orang Raden Saleh muncul dalam karya tersebut : sebagai seorang prajurit yang menunduk kepada pemimpin yang menangkapnya, dan sebagai seorang prajurit yang menghadap ke arah penonton (Carey, 1982 : 5). Diduga Raden Saleh ingin mengungkapkan rasa nasionalismenya dengan menempatkan sosoknya sebagai pendukung Diponegoro, sebuah sikap politik yang masih menjadi perdebatan oleh para ahli sejarah dan seni hingga saat ini.

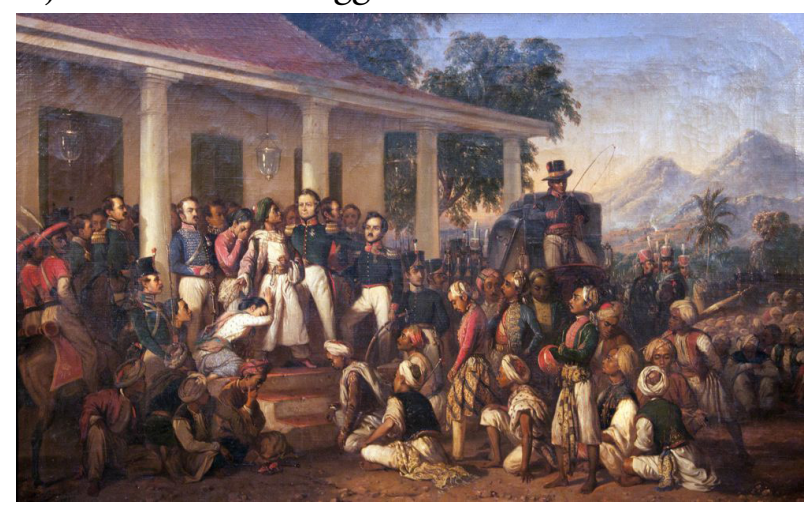

Gambar 3. Lukisan "Penangkapan Pangeran Diponegoro" Karya Raden Saleh

(Sumber : https://id.wikipedia.org/wiki/Penangkapan_ Pangeran_Diponegoro, diakses pada tanggal 4 Oktobèr 2019, pukul 16.25 WIB)
Pada perkembangan selanjutnya, potret diri semakin banyak digunakan oleh para seniman sebagai bahasa ungkap. Pada medio 1930-1960-an, beberapa seniman besar negeri inipun menggambarkan sosok dirinya ke dalam kanvas, seperti Sudjojono melalui karya "Potret Diri dan Karangan Bunga", Hariadi Selobinangun lewat "Potret Diri" (1953), Kusnadi dalam karya "Potret Diri" (1947), Affandi pada karya "Potret Diri \& Topeng-Topeng Kehidupan" (1961), Hendra Gunawan dalam karya "Wajah" dan "Keluarga Gerilya" (1951), Trubus melalui "Potret Diri", Sunarto PR lewat karya "Potret Diri" dan masih banyak lagi. Sebagian besar dari mereka menggambarkan karakteristik sosok mereka dalam gambaran yang formal, serius, tak berekspresi, dan misterius. Sanento Yuliman mendeskripsikan visualisasi yang dipilih oleh para seniman tersebut merupakan karakteristik yang umum digunakan untuk menggambarkan sosok dirinya :

“...sejumlah pelukis menampilkan dirinya sebagai pelukis seniman yang biasa disebut manusia langka, konon, punya kelebihan dan jarang terpahami oleh 'orang kebanyakan'. Mereka terlukis memegang kuas atau palet. Tentu, serius atau berwajah hanyut dalam perasaan." (Yuliman dalam Hasan, 2001 : 201)
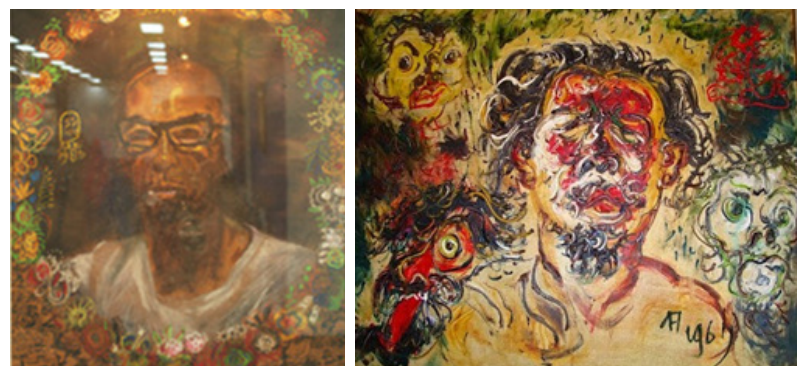

Gambar 4. Karya-karya potret diri seniman Indonesia pada periode 1930-1960an (Sudjojono dan Affandi

(Sumber : https://indoartnow.com/artists/s-sudjojono dan http://indraputraprat.blogspot.com/2014/08/ pelukis-affandi-koesoema-tahun-1961.html pada 7 Oktober 2019, pukul 13.20 WIB)

Pada perkembangan selanjutnya penggambaran potret diri tak lagi hanya sekedar untuk membangun image dan karakteristik belaka, namun juga menjadi kendaraan seniman untuk menyuarakan identitasnya secara lebih mendalam. Karakteristik personal yang berbeda 
antar seniman menjadi hal unik yang coba digali dengan lebih mendalam oleh masing-masing seniman.

\section{Biografi Agus Suwage}

Agus Suwage dilahirkan pada 14 April 1959 di Purworejo. Ia mengenyam pendidikan formal di Jurusan Desain Grafis, Fakultas Seni Rupa dan Desain, ITB Bandung pada tahun 19791986. Suwage merupakan keturuna Tionghoa, Ayahnya adalah seorang pedagang biasa, namun Ibunya berasal dari kalangan pedagang yang cukup berada, maka dari itu, untuk mengimbangi keluarga sang Istri, Ayah Suwage menjadi sosok pekerja keras, ulet dan tak mudah menyerah (Saidi, 2008 : 175). Karakteristik yang kemudian ditularkan dengan sangat baik kepada Suwage yang memiliki etos kerja luar biasa, sebagai bukti, Suwage dalam setahun mampu menghasilkan puluhan karya dan aktif dalam beberapa even besar kesenian. Selain menempuh pendidikan formal, Suwage pun pernah melakukan beberapa residensi di luar negeri, di antaranya di Australia (1996), Jepang (1999-2000) dan Singapura (2003).

Setelah menyelesaikan studinya, Suwage bekerja sebagai desainer pada sebuah perusahaan desain grafis namun jiwanya yang bebas membuatnya tak puas hanya dengan menjadi pegawai, sehingga ia pun akhirnya memutuskan untuk keluar dari pekerjaannya. Ia kemudian mendirikan sebuah studio desain grafis yang bernama Work pada tahun 1989, studio tersebut berdiri hingga tahun 1995 . Suwage kerap berkarya dan melakukan pameran sejak tahun 1985, namun pada tahun 1995 ia memutuskan untuk menjadi seniman secara profesional sepenuhnya, dan menutup studionya tersebut. Selain aktif sebagai desainer dan seniman, Suwage pun aktif berkegiatan sebagai bagian dari Lembaga Swadaya Masyarakat (LSM), bahkan pada tahun 1989 rumahnya pernah menjadi sekretariat bagi para aktivis masyarakat dan mahasiswa yang menggerakkan demonstrasi (Saidi, 2008 : 176). tak mengherankan jika kemudian karya-karya Suwage penuh dengan kritik sosial, mengingat kepeduliannya terhadap lingkungan dan permasalahan sosial di sekitarnya.

Dalam membangun wacana kekaryaan, Suwage kerap menggunakan tubuhnya sebagai representasi dari identitas yang dibangun.
Ia selalu menggambarkan sosoknya sebagai perwakilan dari permasalahan sosial yang terjadi di sekitarnya. Eksplorasi yang dilakukan pun tak hanya terbatas media konvensional dalam seni rupa, namun juga menggunakan beberapa media baru sebagai gaya ungkapnya.

\section{Semiotika}

Semiotika berasal dari bahasa Yunani, Semeion yang berarti tanda atau penunjuk, dan pertama kali digunakan oleh Hippocrates (460-377 SM) (Danesi, 2010 : 6) . Semiotika adalah studi tentang tanda dan segala yang berhubungan dengannya : cara berfungsinya, hubungannya dengan tanda-tanda lain, pengirimannya dan penerimaannya oleh mereka yang mempergunakannya (Sudjiman dan Zoest, 1992 : 5). Sedangkan tanda menurut Kamus Besar Bahasa Indonesia (KBBI) adalah yang menjadi alamat atau yang menyatakan sesuatu; gejala; bukti; pengenal; petunjuk (www. kbbi.kemdikbud.go.id/tanda). Dalam sebuah penafsiran yang lebih kompleks, Arthur Asa Berger mendefinisikan tanda sebagai sesuatu yang terdiri pada sesuatu yang lain atau menambah dimensi yang berbeda pada sesuatu, dengan memakai apapun yang dapat dipakai untuk mengartikan sesuatu yang lainnya (Berger, $2010: 1$ ).

Secara umum, teori semiotika yang digunakan untuk menganalisa tanda dibagi menjadi dua, yaitu teori semiotika signifikasi yang dicetuskan oleh Ferdinand de Saussure dan teori semiotika komunikasi nya Charles S. Pierce. Ada perbedaan yang cukup mendasar antara kedua pendekatan tersebut, pada dasarnya semiotika signifikasi memerlukan bantuan teori kode, sedangkan semiotika komunikasi memerlukan bantuan teori produksi tanda, perbedaan ini seperti yang diungkapkan oleh Umberto Eco berikut :

"Penggolongan setiap gejala dalam signifikasi dan komunikasi bukan suatu kebetulan atau dibuat-buat. Sistem signifikasi itu ada (dan oleh karena itu disebut kode) jika ada kemungkinan menghasilkan fungsi-fungsi tanda yang telah disepakati oleh masyarakat; baik fungsi itu memiliki ciri-ciri tersendiri (yang khas, yang disebut dengan tanda) maupun dalam konteks wacana yang lebih luas, asalkan hubungan itu sebetulnya 
telah diterima oleh konvensi masyarakat, maka cukuplah untuk disebut sistem signifikasi. Sebaliknya proses komunikasi itu terjadi apabila kemungkinankemungkinan yang tersedia dalam sistem signifikasi itu dimanfaatkan secara fisik untuk mengungkapkan maksud-maksud tertentu. (Eco dalam Sudjiman dan Zoest, $1992: 27-28)$

Fokus pembahasan dalam membedah karya seni yang akan dilakukan sekarang ini lebih menitikberatkan pada pendekatan semiotika signifikasi yang diungkapkan oleh Ferdinand de Saussure. Pemilihan metode semiotika signifikasi berdasarkan konteks karya seni yang lebih memungkinkan untuk diinterpretasi secara maksimal dibandingkan dengan semiotika komunikasi yang lebih menitikberatkan kepada tanda dalam komunikasi masal. Secara umum, menurut de Saussure tanda dibentuk oleh concept dan sound-image yang saling melengkapi agar dapat dipahami sebagai sebuah makna.

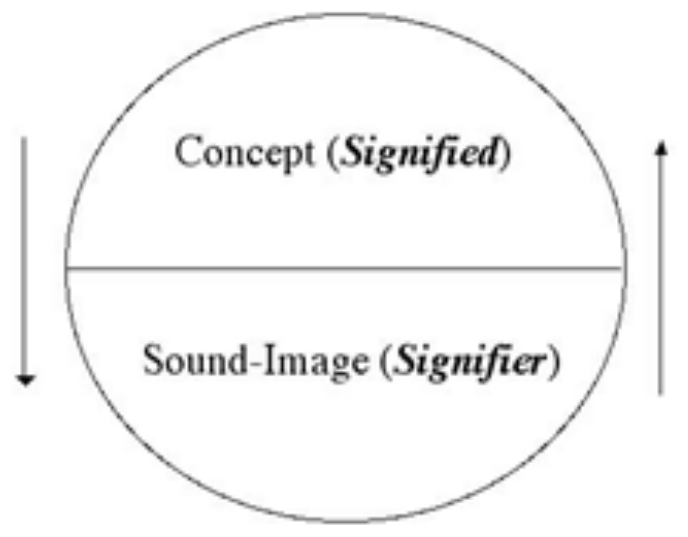

Bagan pembentukan tanda menurut de Saussure (Sumber : Irma Damajanti, Diktat Kuliah Semiotika I)

Hal tersebut dispesifikasikan oleh Roland Barthes untuk mempermudah pembacaan akan sebuah tanda, concept disubstitusi oleh signified (penanda) sedangkan sound-image diganti dengan signifier (petanda) sebagaimana yang ditunjukkan dalam tabel berikut ini :

\begin{tabular}{|c|c|}
\hline Signified & Signifier \\
\hline \multicolumn{2}{|c|}{ Sign } \\
\hline
\end{tabular}

Skema semiotika signifikasi de Saussure menurut Roland Barthes

(Sumber : Irma Damajanti, Diktat Kuliah Semiotika I)
Signified dapat diartikan sebagai bentuk material (fisik) dari suatu tanda, yang dapat dirasakan oleh panca indera sedangkan signifier adalah suatu konstruksi mental (konsep), yang tak dapat dicerap oleh panca indera.

\section{Analisa Politik Identitas dalam Karya-Karya Potret Diri Agus Suwage dengan Pendekatan Semiotika}

Dalam menganalisa kecenderungan yang diambil oleh Agus Suwage, kajian ini berupaya untuk mengkaji latar belakang dari sang sosok seniman. Melihat situasi politik Indonesia, masa di mana ketika Suwage tumbuh, mengenyam bangku pendidikan dan memulai karir kesenimanannya, sedang berlangsung masa orde baru. Pada saat itu, situasi bagi warga negara keturunan terbilang cukup sulit. Dari sana kita bisa membaca betapa pelik dan serba terbatasnya kesempatan Suwage dalam lingkup sosial sebagai warga keturunan Tionghoa. Warga keturunan yang kerap dianggap sebagai minoritas, menjadi titik tolak bagi Suwage dalam membangun identitas politiknya.

Dalam pembahasan yang akan dilakukan, seperti yang telah dijabarkan sebelumnya, penulis akan membatasi setiap pembahasan pada karya yang diciptakan selama dua dekade terakhir, yaitu dari tahun 1999 hingga 2019, dan karya yang menggunakan potret diri Agus Suwage sebagai objek. Untuk efektifitas pembahasan dan efisiensi waktu, kajian selama dua dekade tersebut akan dikerucutkan kepada dua karya, yang masingmasingnya mewakili kurun waktu sekitar 10 tahun, periode 1999-2009 dan 2009-2019. Hal ini juga untuk membaca perubahan sudut pandang Suwage dalam menempatkan 'diri'nya pada realitas yang coba ditafsirkannya melalui karya.

\section{Periode 1999-2008}

Pada periode 1999-2008, Agus Suwage banyak menggambarkan sosoknya serupa manusia setengah babi atau yang menggambarkan sosoknya dengan karakter hewan tersebut dalam karya-karyanya. Babi, dalam negara yang mayoritas penduduknya beragama muslim, memiliki penanda khusus sebagai hewan yang dilabeli sebagai sosok haram yang sebaiknya dihindari dan dijauhi. Idiom ini yang kemudian digunakan Suwage sebagai kendaraannya 
untuk mengekspresikan sosok yang terkucilkan dan dijauhi. Dalam proses pembacaan yang akan dilakukan dalam periode ini, Penulis memutuskan untu mengkaji karya Suwage yang bertajuk "Suwage versus Suwage" di antara karyakarya lainnya. Pemilihan ini didasarkan betapa kuatnya identitas politik yang ingin disampaikan oleh sang seniman, melalui representasi sosok babi tersebut.

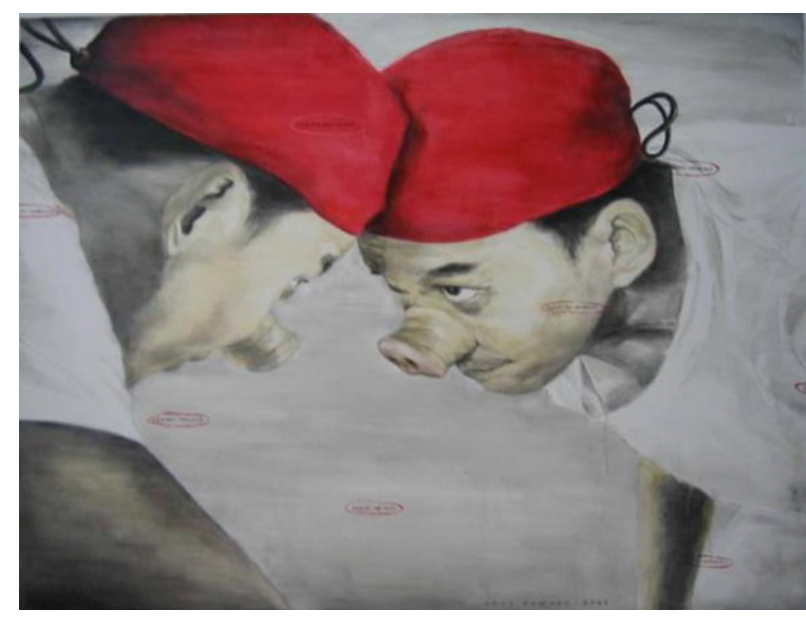

"Suwage versus Suwage"

Cat Minyak pada Kanvas, 165 × 200 cm, 2005

(Sumber: Satrio Hari Wicaksono)

Dengan pembahasan menggunakan teori semiotika signifikasi de Saussure, dalam lukisan ini terdapat beberapa signifier kunci sebagai bahan penganalisaan data, yaitu :

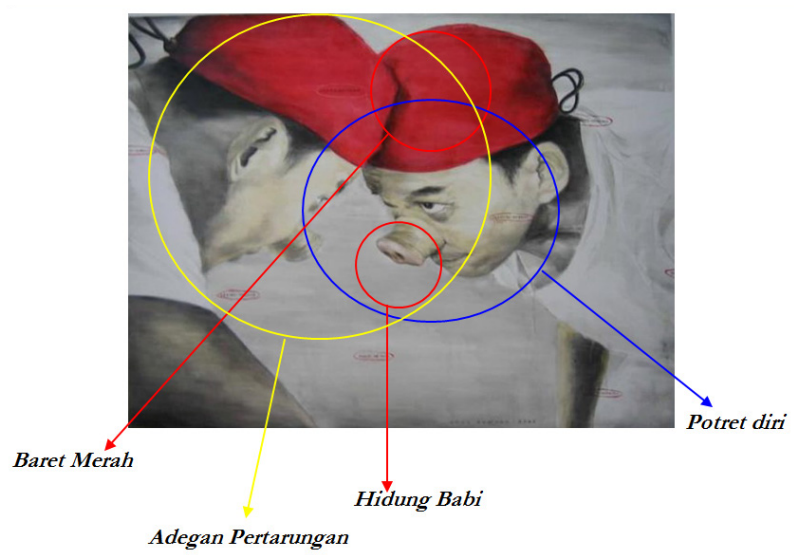

Analisis signifikasi lukisa Agus Suwage (Sumber: Satrio Hari Wicaksono)

Setelah penganalisaan terhadap signifier kunci pada gambar tersebut, yang menjadi signified pada gambar tersebut adalah kesan pertarungan dan persaingan. Dari penganalisaan terhadap signifier dan signified dalam gambar tersebut dapat disimpulkan bahwa sign dalam gambar ini adalah komunikasi yang ingin diungkapkan oleh sang seniman kepada para apresiatornya, penggambaran sebuah ekspresi pribadi tentang sebuah 'permasalahan' yang menjadi kegelisahannya dimana potret diri dijadikan sebuah media melakukan kritisasi.

Kesan persaingan dan pertarungan kuat terasa dalam karya ini. Penggambaran dua sosok yang saling beradu kepala menjadi kunci kehadiran kesan pertarungan yang kuat. Banyak penggunaan bahasa simbolik yang membungkus pembacaan akan visualisasi yang ditampilkan. Salah satunya adalah 'hadirnya' Agus Suwage sebagai sosok dengan tampilan seperti babi, sesosok hewan yang terkesan malas, rakus namun terkadang bisa melakukan tindak kekerasan. Sepertinya ia menempatkan dirinya sebagai babi dalam konteks pengalaman pribadi hidup di Indonesia yang mayoritas penduduknya adalah muslim, yang mengharamkan babi. Dengan ini ia ingin menjadikan dirinya sebagai yang "haram", yang "lain", yang dinistakan dan yang keberadaannya terancam. Sebuah tanggapan kritis terhadap lingkungan sosialnya dengan menjadikan dirinya sendiri sebagai sasaran hinaan dan cacian.

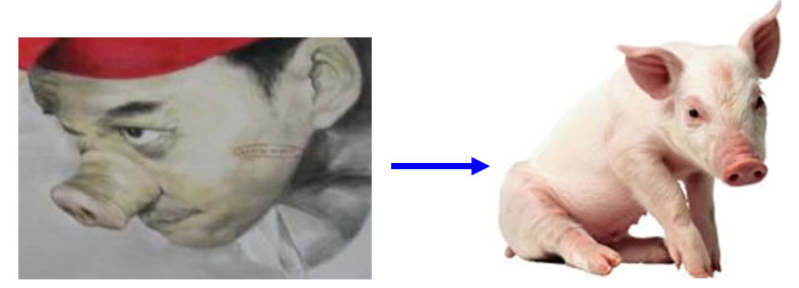

Peminjaman ikon babi dalam karya Agus Suwage (Sumber: Satrio Hari Wicaksono)

Pembahasan selanjutnya adalah penggunaan baret merah yang digunakan oleh sang objek, yang merupakan simbol dari militer. Dalam matra darat militer Indonesia, baret merah dikenakan oleh Komando Pasukan Khusus (KOPASSUS), pasukan militer dimana anggotanya memiliki kemampuan tempur yang elit, kuat dan khusus, sebuah organisasi yang erat kaitannya dengan perang dan kekerasan. Dalam sejarah nya, KOPASSUS dikenal sebagai tempat untuk mendidik perwira-perwira muda yang potensial, yang kemudian hari akan mengisi posisi-posisi sentral di Tentara Nasional Indonesia (TNI), banyak petinggi-petinggi militer negeri ini yang mengawali karirnya di KOPASSUS. 
Di tengah catatan gemilang yang ditorehkan oleh KOPASSUS, organisasi ini mendapatkan stigma buruk ketika pada tahun 1998 dituding sebagai salah satu kelompok yang dianggap bertanggung jawab terhadap hilangnya sejumlah orang dan juga pemicu kerusuhan itu terjadi. Bagi Suwage yang berlatar belakang sebagai warga negara keturunan, yang mengalami salah satu masa terberat pada periode tersebut, tentu punya pandangan yang berbeda terhadap militer, khususnya pasukan baret merah.

Baret merah disini hadir sebagai pengulangan dan 'penguat' narasi serta kesan pertempuran dan persaingan antara kedua sosok tersebut. Tatapan mata sang sosok dalam karya itu pun juga menggambarkan sikap intimidatif yang berusaha untuk 'menekan' lawannya.

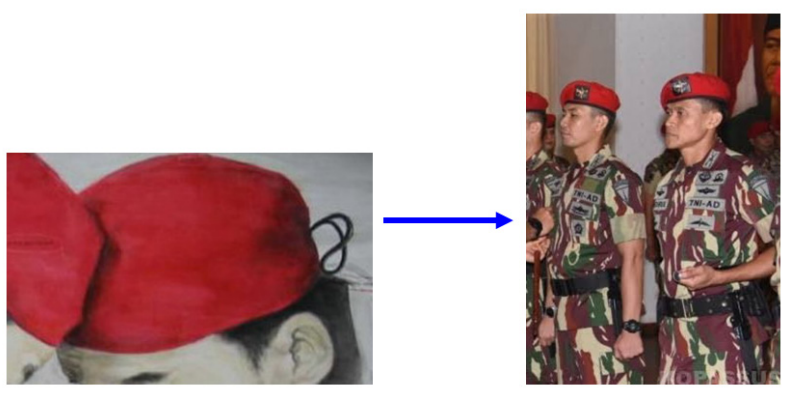

Baret merah sebagai simbol dari militer, khususnya KOPASSUS

(Sumber: Satrio Hari Wicaksono)

Penggambaran dua sosok yang serupa, sebagai gambaran dari sosok seniman itu sendiri yang saling beradu kepala mengarahkan kita, para apresiator untuk menduga bahwa gambar ini merepresentasikan sebuah simbolisasi dari peperangan terhadap 'diri sendiri' atau kelompok kita sendiri. Posisi kepala yang saling mengadu menggambarkan persaingan antar sosok yang setara namun seolah ingin memenangkan hegemoni.

Dari semua penanda dan petanda yang dibahas di atas, bisa ditarik kesimpulan apa yang ingin digambarkan oleh Suwage dalam karya ini adalah representasi sosok dirinya yang terjebak dalam konflik horizontal antar kelompoknya, kelompok minoritas, yang dipandang sebelah mata dan dikucilkan. Ada sebuah pembacaan yang ambigu seputar penggunaan baret merah yang dikenakan oleh kedua sosok Suwage, yang pertama adalah menggambarkan tentang pertarungan sekuat tenaga layaknya pertarungan militer antar dua kelompok yang berimbang atau dari kelompok yang sama. Kedua, pertarungan horizontal antar sesamanya, sesama kelompok minoritas yang dimanfaatkan oleh sekelompok orang yang berideologi militer.

\section{Periode 2009-2019}

Pada periode ini, tak terlalu banyak karya Suwage yang mengeksplorasi tentang potret diri, walaupun ada sebagian karya yang tetap menempatkan sosoknya sebagai bagian dari politik identitasnya. Dari beberapa karya yang kemudian mengangkat identitas diri, penulis memilih karya berjudul "Dogma Bertumpuk \#3", yang penulis rasa mampu menghadirkan representasi sosial pada masa itu.

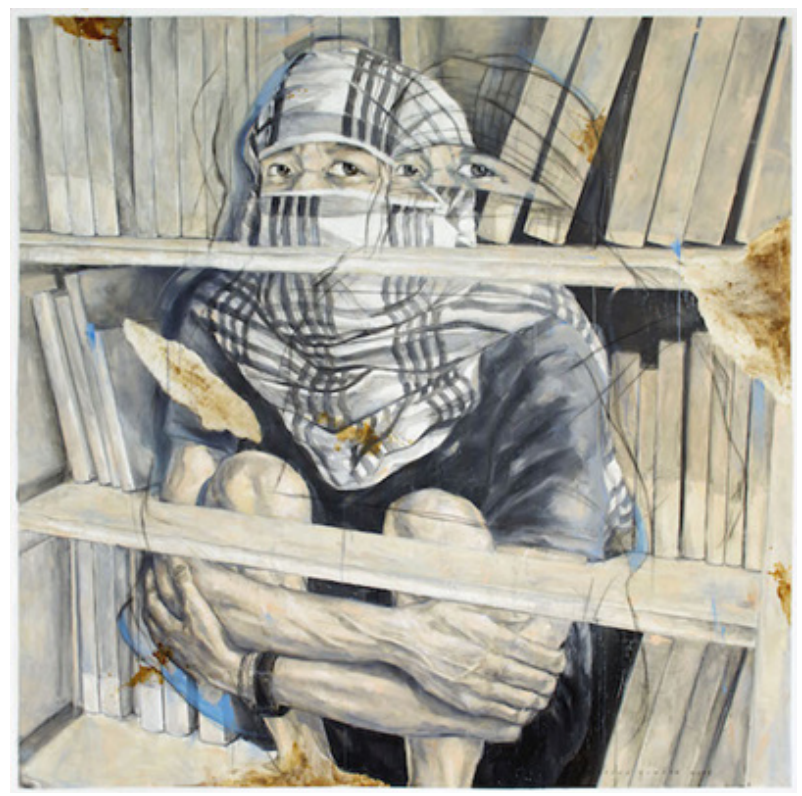

Dogma Bertumpuk \#3, oil, lasur on canvas, 2018 (Sumber: Satrio Hari Wicaksono)

Ada beberapa signifier kunci yang akan dikaji dalam karya ini sebagai penanda untuk bahan kajian untuk membahas pemaknaan yang terkandung dalam karya. Beberapa penanda itu adalah : 


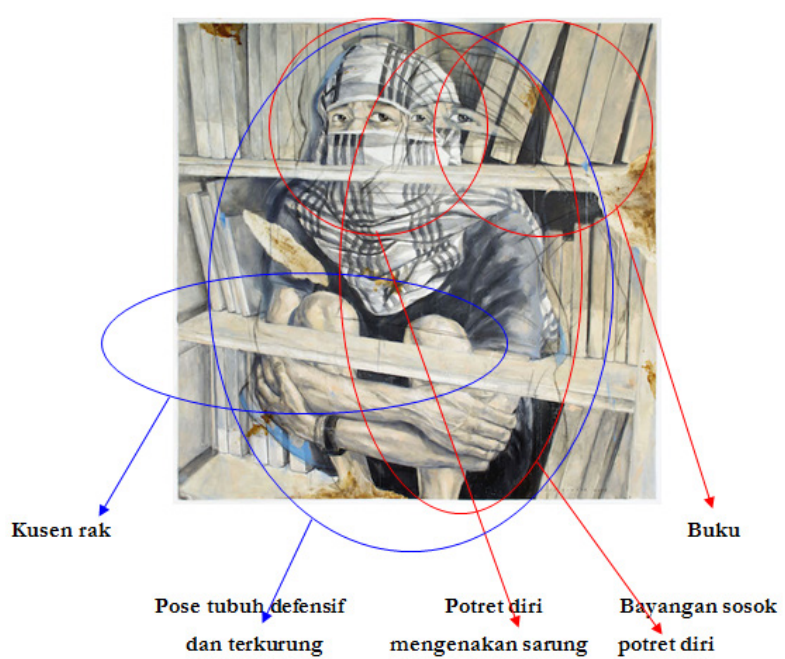

Analisis Signifikasi lukisan Agus Suwage (Sumber: Satrio Hari Wicaksono)

Setelah pembacaan terhadap signifier kunci yang dijabarkan di atas, signified yang terbaca adalah posisi pose tubuh yang terkungkung dalam rak wacana. Dari penganalisaan terhadap signifier dan signified dalam gambar tersebut dapat disimpulkan bahwa sign dalam gambar ini adalah penandaan terhadap unsur-unsur signifier yang dijabarkan sebelumnya. Penggunaan judul Dogma menjadi kata kunci yang cukup penting untuk memetakan inti dari narasi yang dibangun oleh sang seniman. Kata dogma berarti 1 pokok ajaran (tentang kepercayaan dan sebagainya) yang harus diterima sebagai hal yang benar dan baik, tidak boleh dibantah dan diragukan; 2 keyakinan tertentu (https://kbbi.web.id/dogma). Penggunaan kata dogma menggiring narasi tentang karya kepada hal yang bersifat religi.

Penggambaran pose dari Suwage yang terkurung dalam rak buku merepresentasikan tentang objek yang terkurung dalam wacana sempit. Sosok figure yang berbayang seolah menggambarkan identitas yang terkaburkan, yang mulai menghilang dan terkurung dalam lingkup dogma yang sempit. Penggambaran buku yang tak terlihat punggung bukunya ditafsirkan sebagai sumber wacana yang tak terlalu jelas sumbernya, yang bisa berisi muatan apapun tanpa dasar keilmuan yang mampu dipertanggung jawabkan.

Penggunaan sarung sebagai penutup wajah juga merupakan representasi dari ketertutupan dari hal lain, seolah menutup diri dari informasi lainnya, hanya bersumber dari sebuah wacana yang dianggapnya paling benar. Selain itu, penggunaan sarung juga identik sebagai perlengkapan ibadah yang kerap digunakan oleh kaum muslim di Indonesia. Secara garis besar dapat dikatakan bahwa ini merupakan kritik dari Suwage terhadap fenomena belakangan ini tentang kaum-kaum radikal yang memiliki dogma sempit, yang menutup diri terhadap informasi, perkembangan, dan situasi lingkungan sekitarnya.

\section{Simpulan}

Kajian yang dilakukan ini untuk membaca karakteristik dan perkembangan karyakarya potret diri Agus Suwage sekaligus membaca situasi medan sosial yang berkecamuk ketika karya tersebut dihasilkan. Pembacaan tanda-tanda yang hadirdalamkarya menggunakanmetodesemiotika, dimana fokus pembahasan dalam membedah karya seni yang akan dilakukan sekarang ini lebih menitikberatkan pada pendekatan semiotika signifikasi yang diungkapkan oleh Ferdinand de Saussure. Pemilihan metode semiotika signifikasi berdasarkan konteks karya seni yang lebih memungkinkan untuk diinterpretasi secara maksimal dibandingkan dengan semiotika komunikasi yang lebih menitikberatkan kepada tanda dalam komunikasi masal.

Dalam memposisikan dirinya sebagai bagian dari lingkup sosial secara luas, Suwage selalu mengedepankan identitas personalnya sebagai bagian dari warga minoritas yang kerap mengalami perlakuan yang 'tidak adil'. Suwage selalu melakukan 'empati' dengan merepresentasikan dirinya sebagai pelaku sekaligus objek yang berada dalam situasi sosial yang dihadirkan dalam karya, bahkan tak jarang Suwage meminjam gaya ungkap dari seniman lainnya sebagai media untuk memperbandingkan situasi sosial ketika karya itu dihasilkan dan kondisi ketika karya Suwage diproduksi, seperti dalam karya berjudul "Maka Lahirlah Angkatan 90-an" yang meminjam karakteristik visual dari karya Sudjojono berjudul "Maka Lahirlah Angkatan 66". Pemilihan karakter yang cenderung absurd, karakteristik warna yang cenderung pucat dan monokromatik menggambarkan kecenderungan kesan sebuah penggambaran situasi yang tidak menyenangkan, sedih dan suram.

Secara sadar penulis merasakan banyak sekali kekurangan yang belum terpenuhi untuk menjadikan tulisan ini sebuah kajian yang baik. Untuk itu kritik dan saran sangat diperlukan untuk membangun ketajaman isi dan hasil dari penelitian ini. 


\section{Daftar Pustaka}

\section{Buku :}

Barthes, Roland (2017), Elemen-Elemen Semiologi, Penerbit BasaBasi, Yogyakarta

Berger, Arthur Asa (2010), Pengantar Semiotika, Tanda-Tanda Dalam Kebudayaan Kontemporer, Penerbit Tiara Wacana, Yogyakarta

Carey, Peter (1982), Raden Saleh, Dipanegara and the Painting of the Capture of Dipanegara at Magelang, Journal of the Malaysian Branchof the Royal Asiatic Society 55-1 : 1-26

Damajanti, Irma (2007), Diktat Perkuliahan Semiotika I, Fakultas Seni Rupa dan Desain Institut Teknologi Bandung, Bandung

Danesi, Marcel (2010), Pesan, Tanda dan Makna, Buku Teks Dasar Mengenai Semiotika dan Teori Komunikasi, Penerbit Jalasutra, Yogyakarta

Hasan, Asikin (ed) (2001), Dua Seni Rupa Sepilihan Tulisan Sanento Yuliman, Kalam, Jakarta

Maarif, Ahmad Dyafii (2012), Politik Identitas dan Masa Depan Pluralisme Kita, Democracy Project, Jakarta

Saidi, Acep Iwan (2008), Narasi Simbolik Seni Rupa Kontemporer Indonesia, Isacbook, Yogyakarta

Sudjiman, Panuti dan Aart van Zoest (1992), Serba-Serbi Semiotika, PT Gramedia Pustaka Utama, Jakarta

Sudjojono, S. (2000), Seni Lukis, Kesenian dan Seniman, Yayasan Aksara Indonesia, Yogyakarta

Susanto, Mike (2011), Diksi Rupa, Kumpulan Istilah \& Gerakan Seni Rupa, DictiArt Lab \& Jagad Art Space, Yogyakarta

Wicaksono, Adi, dkk.(ed) (2002), Aspek-Aspek Seni Visual Indonesia : Identitas dan Budaya Massa, Yayasan Seni Cemeti, Yogyakarta.

\section{Jurnal :}

Prajitno, Hari (2018), Identitas dan Seni dalam Realitas Perubahan: Tantangan Penciptaan, bagi Seniman dan Akademisi, Jurnal Lembar, Jurnal Seni dan Budaya, vol.1 - no. 1Oktober - Desember 2018, Penerbit Nyala, Yogyakarta

\section{Katalog :}

Supangkat, Jim, Asmudjo J. Irianto, Rizki A. Zaelani (1999), Pameran Modernitas Indonesia dalam Representasi Seni Rupa, 8 Mei - 8 Juni 1999, Galeri Nasional Indonesia, Jakarta

\section{Website :}

www.kbbi.kemdikbud.go.id/identitas

www.kbbi.kemdikbud.go.id/tanda 